\title{
CHEMICAL CHARACTERISTICS OF MANGO (Mangifera indica L.) KERNEL OIL AND PALM OIL BLENDS FOR PROBABLE USE AS VANASPATI
}

\author{
ATTA MUHAMMAD ARIF*; IRMAN JAVED*; MUHAMMAD ABDULLAH; MUHAMMAD IRMAN**; ATHAR \\ MAHMUD $¥ \neq ;$ MUHAMMAD NADEEM* and MUHAMMAD AYAZ*
}

\begin{abstract}
Chemical characteristics of blends of palm oil and mango kernel oil for their probable use as vanaspati was studied. Crude mango kernel oil was blended with refined, bleached and deodorised palm oil from $10 \%, 20 \%, 30 \%, 40 \%$ and $50 \%\left(T_{1}, T_{2^{\prime}} T_{3^{\prime}} T_{4}\right.$ and $\left.T_{5}\right)$ market vanaspati was used as control. Concentration of trans fatty acids in control was $22.7 \%$, whereas, all the vanaspati samples were virtually trans-free. Slip melting points $\left({ }^{\circ} \mathrm{C}\right)$ of control, $T_{1^{\prime}}, T_{2^{\prime}} T_{3^{\prime}} T_{4}$ and $T_{5}$ were 37.5, 37.3, 36.4, 35.6, 34.8 and 34. Free fatty acids of control and T5 were respectively 0.11, $0.12 \%$. Polymer contents of control, $T_{1}, T_{2}, T_{3}, T_{4}$ and $T_{5}$, after three heating cycles $\left(180^{\circ} \mathrm{C}\right.$, for $8 \mathrm{hr}$ ) were $21.55 \%, 20.97 \%, 18.66 \%, 17.61 \%$ and $10.22 \%$, respectively with lower solid fat index $(p<0.05)$. Blends of mango kernel oil and palm oil can be used for the formulation of trans-free vanaspati.
\end{abstract}

Keywords: mango kernel oil, palm oil, vanaspati, trans fatty acids, storage stability.

Date received: 20 May 2015; Sent for revision: 8 December 2015; Received in final form: 27 July 2016; Accepted: 28 July 2016.

\section{INTRODUCTION}

Vanaspati was developed about 80 years back in India, as an alternate of Desi ghee, which is either prepared from milk fat of cows, buffaloes or blend of thereof. Vanaspati is a vegetable oil-based product, refining, bleaching, hydrogenation and deodorisation are usually regarded as the integral phases of its production (Nadeem et al., 2014). In the subcontinent, it is used for the purpose of cooking,

\footnotetext{
Department of Dairy Technology, University of Veterinary and Animal Sciences Lahore, Lahore, 54000 Punjab, Pakistan. E-mail: sheikhnadeem@live.com

** Department of Food Science, Government College University Faisalabad, Faisalabad, 38000 Punjab, Pakistan.

‡ Department of Livestock Production, University of Veterinary and Animal Sciences Lahore, Lahore, 54000 Punjab, Pakistan.

\# Department of Poultry Production, University of Veterinary and Animal Sciences Lahore, Lahore, 54000 Punjab, Pakistan.
}

frying, preparation of a wide variety of culinary traditional sweets and as a bakery shortening. The versatile usages of vanaspati in India-Pakistan, West Asian and South Asian countries have steered to a considerable increase in its production during the last few decades. Initially, the vanaspati was formulated from hydrogenated cottonseed oil or groundnut oil. With the advancement of edible oil processing industry; palm oil, palm olein, soyabean, sunflower, and canola oils became more popular over the traditional oils (Shahidi, 2005). Vanaspati is solid at room temperature with wide range of variation in physical, chemical and textural characteristics. The product is usually designed in such a way that it remains solid in hot summer of the subcontinent. Blends are adjusted according to the season, availability and prices of locally produced oils. However, palm oil $/ \mathrm{palm}$ olein an integral part of vanaspati, about 70\%$80 \%$ of the vanaspati is constituted of either palm 
oil/palm olein. Hydrogenation is an important step in the manufacturing of vanaspati; it allows manufacturers to adjust their products according to the seasons, to manufacture wide range of formulations of different melting point, solid fat index and textural characteristics (Leth et al., 2003). Hydrogenation of edible oils also adds up the additional processing steps of post-refining and post-bleaching in the hydrogenated stuffs, which not only increases the process loss, but also increases the processing cost. Hydrogenation of edible oils is a costly affair, expensive nickel catalyst, lot of energy and hydrogen gas is required to transform the liquid oils into semi-solid stuffs. The excessive residues of nickel catalyst in vanaspati may have serious health hazards (Alonso et al., 2000). The role of partial hydrogenation in the generation of harmful trans fatty acids is well established (Tekin et al., 2002). Most of the trans fatty acids enter in the human body through the ingestion of partially hydrogenated fats, trans fatty acids are not required for any physiological function in human body, rather they increase the bad LDL cholesterol and decrease the beneficial HDL cholesterol (Lokuruka 2007). The new sources of dietary lipids must be discovered to formulate health friendly foods which require minimum processing. Rapidly diminishing energy sources and increased consciousness about nutrition associated health disorders requires the production of minimally processed foods. The potential health benefits of monounsaturated fatty acids have been scientifically proven; therefore, it is the need of hour to develop foods having higher extents of these fatty acids (Mensink et al., 2002). Fatty acid composition and physical properties of palm oil makes it versatile oil to formulate the large number of trans-free options. The suitability of non-traditional oils in the formulation of transfree vanaspati has been documented (Nadeem et al., 2014). Mango (Mangifera indica L.) belongs to the genus Angifera, family Anacardiaceae (Fowomola, 2010). The kernel is comprised of about $20 \%$ of the fruit, it contains about $11 \%-14 \%$ good quality edible oil, which does not require any processing (Pott et al., 2003). The fatty acid composition and physical properties suggest wide range of opportunities in trans options. This study aimed to determine the suitability of mango kernel oil, palm blends as vanaspati substitutes on the basis of fatty acid profile, solid fat, index, melting point, sensory and storage stability characteristics.

\section{MATERIALS AND METHODS}

\section{Materials}

Oil was extracted from the mango kernel (Chaunsa variety) by mechanical expression, stored at $-18^{\circ} \mathrm{C}$ for further usage in current investigation. GC grade chemicals were used in this investigation (Sigma Aldrich, St Louis MO, USA).

\section{Experimental Plan}

Mango kernel oil was blended with palm oil at $10 \%, 20 \%, 30 \%, 40 \%$ and $50 \%$ concentrations $\left(\mathrm{T}_{1}, \mathrm{~T}_{2}, \mathrm{~T}_{3}, \mathrm{~T}_{4}\right.$ and $\left.\mathrm{T}_{5}\right)$, and market vanaspati served as control. Experimental samples along with the control were packaged in tin containers of $1 \mathrm{~kg}$ capacity, stored at ambient temperature $\left(25^{\circ} \mathrm{C}-30^{\circ} \mathrm{C}\right)$ for 6-month, relative humidity $40 \%-50 \%$, with no direct contact with sunlight. All the treatments and control were sampled at every two-month, till six months of storage period.

\section{Analysis}

Fatty acid composition was determined by transforming the fatty acids into methyl esters, methanolic $\mathrm{HCl}(15 \%$, Fluka) was used as a transesterifying agent, $10 \mu \mathrm{l}$ was injected into GC (17-A, Shimadzu, Japan) using $100 \mathrm{~m}$ long fused capillary column with inner diameter $0.22 \mathrm{~mm}$ (Zebron Phenomenex) using helium as a carrier gas at the rate of $2.5 \mathrm{ml} \mathrm{min}^{-1}$, with a total runtime of 42 min. Fatty acid methyl esters FAME-37 kit (Sigma Aldrich, United Kingdom) was used to identify and quantify the individual fatty acids (Qian, 2003). Proximate composition of mango kernel was determined by the standard methods (AOAC,

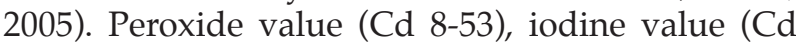
1d-92), free fatty acids (Ca 5a-40), saponification value (cd 3 25), unsaponifiable matter (Ca 6b-53), solid fat index (Cc 7-25), slip melting point were determined by open capillary tube method (Cc 3-25) (AOCS, 1995). Induction period was determined on Rancimat (Model 679), briefly, 2.5 g representative sample was taken into the reaction vessel, oxidised at $120^{\circ} \mathrm{C}$ under a constant flow of oxygen at 20 litres $\mathrm{hr}^{-1}$; the cut-off point in the curve was used as a sign of induction period (Metrohm, 1993). Polymer content of mango kernel oil-based vanaspati was determined by the method of AOAC (1997). Samples were heated to $180^{\circ} \mathrm{C}$ and held for $8 \mathrm{hr}$, three cycles of each heating were repeated. Sensory evaluation of vanaspati formulated from mango kernel oil and palm oil was performed according to the standard method of the American Oil Chemists Society ( $\mathrm{Cg}$ 2-83:1983) (Rass et al., 2008). Samples of vanaspati and French fries prepared in them were evaluated for colour, smell and taste by a panel comprised of eight trained judges. Sensory evaluation was performed in individual sensory evaluation booths at $20 \pm 2{ }^{\circ} \mathrm{C}$, black tea was provided to clean the palate in between the evaluations, experimental samples and control were rated on a nine-point scale. The experiment was planned in a completely 
randomised design, the data of the triplicate experiment of each treatment and triplicate analysis of each sample were reported as mean $\pm S D$, analysed by SAS 9.1 software, the treatments were compared by Duncan's Multiple Range Test (Steel et al., 1997).

\section{RESULTS AND DISCUSSION}

Chemical characteristics of mango kernel oil revealed the moisture content of $8.69 \%$, free fatty acids, $0.22 \%$; saponification value, 194; unsaponifiable matter, 1.59\%; iodine value, 55.8; peroxide value, $0.31\left(\right.$ meqO $\left.\mathrm{kg}^{-1}\right)$; refractive index, 1.452; melting point, $32.6^{\circ} \mathrm{C}$; specific gravity, 0.93 ; colour (Red and Yellow, Lovibond Scale), 3.1. physico-chemical characteristics of mango kernel oil recorded in the current investigation are not different from the previously reported research work (Fahimdanesh and Bahrami, 2013).

\section{Chemical Characteristics}

The results of chemical characteristics of blends of mango kernel oil and palm oil are given in Table 1. Free fatty acids of $T_{3}, T_{4}$ and $T_{5}$ were not different from control $(p>0.05)$, while the concentration of free fatty acids in $\mathrm{T}_{1}$ and $\mathrm{T}_{2}$ was less than control $(p<0.05)$. Free fatty acids of the parent palm oil and mango kernel oil were $0.08 \%$ and $0.16 \%$, respectively. For a better storage and flavour stability of fats, the values of free fatty acids should be as low as possible; however, the value of $0.16 \%$ is usually regarded as an acceptable limit for vanaspati. The role of free fatty acids in the development of an objectionable flavour in fats and oils has been well established (Erickson, 1999). The greater values of free fatty acids usually perceive the inferior storage and flavour stability. Iodine value determines the amount of unsaturation and also gives an indication of the anticipated oxidative stability of fats and oils, higher iodine value usually limits the shelf-life (Xu et al., 2007). The iodine value of palm oil was 53.2 and mango kernel oil was 55.8, the difference in iodine value of control and T5 was only 2.09 points. Iodine value of mango kernel oil in previously reported studies was 55 (Kittiphoom and Sutasinee, 2013). Saponification value is a measure of the number of milligrams of $\mathrm{KOH}$ required for saponification, the saponification value of mango kernel oil, palm oil and their blends were not different from each other $(p>0.05)$ with a significant difference in unsaponifiable matter of the control and treatments $(p<0.05)$. The difference in unsaponifiable matter of control and experimental samples could be due to the employment of crude mango kernel oil in blends, whereas, control was comprised of a blend of refined, bleached and deodorised oils. Refining had a critical effect on unsaponifiable matter; unsaponifiable matter in refined oils is normally less than the crude oils (Shahidi, 2005). From the viewpoints of consuming patterns, solid fats are preferred in subcontinent, belief of people that solid fats impart better taste to foods has led to a considerable increase in the consumption of vanaspati. The melting point of vanaspati is always an important parameter for edible oil processors in the subcontinent, usually it ranges from $34^{\circ} \mathrm{C}-38^{\circ} \mathrm{C}$ in winter and summer seasons, the considerable variation from these limits could have a serious impact on acceptability. The use of mango kernel oil in the formulation of vanaspati can permit the oil processor to develop a wide range of trans-free options without hydrogenation, in both winter and summer seasons.

TABLE 1. CHEMICAL CHARACTERISTICS OF MANGO KERNEL OIL AND PALM OIL BLENDS

\begin{tabular}{|c|c|c|c|c|c|c|}
\hline Treatments & FFA $\%$ & Iodine value & Sap. value & USM $\%$ & Colour $(R+Y)$ & MP \\
\hline Control & $0.11 \pm 0.02 a$ & $57.22 \pm 1.09 a$ & $191 \pm 2.43 a$ & $0.67 \pm 0.02 b$ & $50 \pm 1.1 a$ & $37.5 \pm 0.2 \mathrm{a}$ \\
\hline $\mathrm{T}_{1}$ & $0.08 \pm 0.01 c$ & $53.72 \pm 0.88 c$ & $192 \pm 2.54 \mathrm{a}$ & $0.73 \pm 0.03 b$ & $50 \pm 1.0 \mathrm{a}$ & $37.3 \pm 0.1 \mathrm{a}$ \\
\hline $\mathrm{T}_{2}$ & $0.10 \pm 0.02 b$ & $54.01 \pm 1.26 b$ & $190 \pm 1.72 \mathrm{a}$ & $0.78 \pm 0.04 a$ & $48 \pm 1.3 a$ & $36.4 \pm 0.3 b$ \\
\hline $\mathrm{T}_{3}$ & $0.11 \pm 0.03 a$ & $54.37 \pm 0.52 b$ & $196 \pm 3.69 a$ & $0.81 \pm 0.02 \mathrm{a}$ & $49 \pm 1.1 \mathrm{a}$ & $35.6 \pm 0.2 \mathrm{c}$ \\
\hline $\mathrm{T}_{4}$ & $0.11 \pm 0.02 \mathrm{a}$ & $54.82 \pm 1.23 b$ & $189 \pm 2.43$ & $0.83 \pm 0.03 a$ & $47 \pm 1.2 \mathrm{a}$ & $34.8 \pm 0.1 \mathrm{~d}$ \\
\hline $\mathrm{T}_{5}$ & $0.12 \pm 0.03 a$ & $55.13 \pm 1.46 b$ & $193 \pm 4.76$ & $0.85 \pm 0.04 a$ & $48 \pm 1.0 \mathrm{a}$ & $34.0 \pm 0.2 \mathrm{e}$ \\
\hline
\end{tabular}

Note: Means denoted by a different letter in a column are different $(\mathrm{P}<0.05)$.

FFA - free fatty acids.

USM - unsaponifiable matter.

Colour - Lovibond Tintometer Scale (5.25” Quartz Cell).

MP - melting point $\left({ }^{\circ} \mathrm{C}\right)$.

Sap. value - saponification value.

Control: market vanaspati (hydrogenated stuff).

$\mathrm{T}_{1}: 90 \%$ palm oil and 10 mango kernel oil.

$\mathrm{T}_{2}: 80 \%$ palm oil and 20 mango kernel oil.

$\mathrm{T}_{3}: 70 \%$ palm oil and 30 mango kernel oil.

$\mathrm{T}_{4}: 60 \%$ palm oil and 40 mango kernel oil.

$\mathrm{T}_{5}: 50 \%$ palm oil and 50 mango kernel oil. 


\section{Fatty Acid Composition}

The results of the fatty acid composition of vanaspati prepared from palm oil and mango kernel oil blends is presented in Table 2. Blending of palm oil and mango kernel oil in different proportions induced significant changes around C16:0, C18:0, C18:1 and C18:2. The concentration of C16:0 decreased as a function of addition of mango kernel oil, C18:1 content of $\mathrm{T}_{5}$ was $11.9 \%$ greater than control. According to the available scientific information, enhancement of C18:1 in blends had a health beneficial effect, the role of C18:1 in the reduction of bad LDL cholesterol is scientifically proven (Lokuruka, 2007). Control exhibited the higher concentration of trans fatty acids, whereas, the blends of palm oil and mango kernel oil were virtually trans-free. The increased knowledge of nutrition and health related disparities associated with the intake of trans fatty acids has led to a significant decline in popularity of vanaspati. The hot climate of the subcontinent does not favour the storage of oils and fats. Traditionally, vanaspati and cooking oils are displayed outside the shops in the sun in tin containers, this can enhance the oxidative breakdown and partially hydrogenated stuffs generally have better auto-oxidative stability. The existence of lower concentration of C18:2 in mango kernel oil and palm oil blends provided the superior oxidative stability at ambient temperature over the control. In the current investigation, the fatty acid composition of mango kernel oil was slightly different from the previous report (Kittiphoom and Sutasinee, 2013). The variation in fatty acid composition could be correlated with the different variety, soil and agronomic practices. Enhancement of unsaturated fatty acids in trans-free vanaspati through a non-traditional oil has been reported (Nadeem et al., 2014). Butter oil was blended with mango kernel oil from 5\%-20\% concentrations, blending had a major impact on fatty acid composition (Nadeem et al. 2016). Fatty acid profile of watermelon seed oil and mango kernel oil blends was different from the substrate oils (Azeem et al., 2015).

\section{Peroxide Value}

The results regarding the peroxide value of various treatments of blends of palm oil, mango kernel oil are mentioned in Table 3. The peroxide value of the freshly prepared experimental samples were not different from control $(p>0.05)$. The rest of the determination frequencies revealed that peroxide value of all the treatments and the control numerically increased throughout the storage period. The rise of peroxide value in control and experimental samples were different from each other, after 180 days of the storage period, shoot up of peroxide value was in the order of control $>\mathrm{T}_{1}>$ $\mathrm{T}_{2}>\mathrm{T}_{3}>\mathrm{T}_{4}>\mathrm{T}_{5}$. Fatty acid composition of blends and phenolic contents in mango kernel oil were major factors controlling the shoot up of peroxide value during the storage period of 180 days. The C16:0, C18:0 and C18:1 were the major fatty acids in blends, whereas, C16:0, C18:0, C18:1 and C18:2 were the major fatty acids in control, the lower peroxide value in experimental samples at all the

TABLE 2. FATTY ACID COMPOSITION OF MANGO KERNEL OIL AND PALM OIL BLENDS

\begin{tabular}{cllllll}
\hline Fatty acid & Control & \multicolumn{1}{c}{$\mathbf{T}_{\mathbf{1}}$} & \multicolumn{1}{c}{$\mathbf{T}_{2}$} & $\mathbf{T}_{3}$ & $\mathbf{T}_{4}$ \\
\hline $\mathrm{C} 14: 0$ & --- & $0.96 \pm 0.04 \mathrm{a}$ & $0.89 \pm 0.02 \mathrm{~b}$ & $0.82 \pm 0.05 \mathrm{c}$ & $0.76 \pm 0.02 \mathrm{~d}$ & $0.69 \pm 0.03 \mathrm{e}$ \\
$\mathrm{C} 16: 0$ & $13.2 \pm 0.25 \mathrm{f}$ & $39.79 \pm 1.27 \mathrm{a}$ & $36.19 \pm 2.43 \mathrm{~b}$ & $32.73 \pm 0.64 \mathrm{c}$ & $30.91 \pm 1.15 \mathrm{~d}$ & $27.33 \pm 1.65 \mathrm{e}$ \\
$\mathrm{C} 18: 0$ & $16.5 \pm 0.78 \mathrm{f}$ & $11.24 \pm 0.68 \mathrm{e}$ & $15.33 \pm 0.79 \mathrm{~d}$ & $19.64 \pm 0.96 \mathrm{c}$ & $24.19 \pm 0.73 \mathrm{~b}$ & $29.42 \pm 1.12 \mathrm{a}$ \\
$\mathrm{C} 18: 1$ & $30.2 \pm 1.62$ (cis) & $37.56 \pm 0.92 \mathrm{c}$ & $38.71 \pm 1.35 \mathrm{c}$ & $39.28 \pm 1.76 \mathrm{~b}$ & $40.29 \pm 1.17 \mathrm{~b}$ & $41.89 \pm 2.19 \mathrm{a}$ \\
$\mathrm{C} 18: 2$ & $22.7 \pm 0.83 \mathrm{a}$ (trans) & $5.65 \pm 0.14 \mathrm{~b}$ & $5.87 \pm 0.63 \mathrm{~b}$ & $5.92 \pm 0.35 \mathrm{~b}$ & $5.99 \pm 0.11 \mathrm{~b}$ & $6.11 \pm 0.08 \mathrm{~b}$ \\
$\mathrm{C} 18: 3$ & --- & $0.23 \pm 0.02 \mathrm{~d}$ & $1.84 \pm 0.09 \mathrm{a}$ & $1.51 \pm 0.16 \mathrm{~b}$ & $0.42 \pm 0.02 \mathrm{c}$ & $0.29 \pm 0.04 \mathrm{~d}$ \\
\hline
\end{tabular}

Note: Within a row, means sharing a different letter are different $(\mathrm{P}<0.05)$. Refer Table 1 for the detail of treatments.

TABLE 3. PEROXIDE VALUE OF MANGO KERNEL OIL AND PALM OIL BLENDS

\begin{tabular}{lllll}
\hline Treatments & 0 Day & 60 Days & 120 Days & 180 Days \\
\hline Control & $0.32 \pm 0.02 \mathrm{~h}$ & $0.89 \pm 0.05 \mathrm{e}$ & $1.47 \pm 0.18 \mathrm{c}$ & $2.29 \pm 0.35 \mathrm{a}$ \\
$\mathrm{T}_{1}$ & $0.25 \pm 0.04 \mathrm{~h}$ & $0.61 \pm 0.12 \mathrm{f}$ & $0.92 \pm 0.06$ & $1.71 \pm 0.10 \mathrm{~b}$ \\
$\mathrm{~T}_{2}$ & $0.29 \pm 0.05 \mathrm{~h}$ & $0.52 \pm 0.19 \mathrm{~g}$ & $0.87 \pm 0.11 \mathrm{e}$ & $1.44 \pm 0.17 \mathrm{c}$ \\
$\mathrm{T}_{3}$ & $0.32 \pm 0.03 \mathrm{~h}$ & $0.51 \pm 0.11 \mathrm{fg}$ & $0.95 \pm 0.05 \mathrm{e}$ & $1.13 \pm 0.08 \mathrm{~d}$ \\
$\mathrm{~T}_{4}$ & $0.35 \pm 0.04 \mathrm{~h}$ & $0.48 \pm 0.07 \mathrm{~g}$ & $0.84 \pm 0.10 \mathrm{e}$ & $0.92 \pm 0.03 \mathrm{e}$ \\
$\mathrm{T}_{5}$ & $0.24 \pm 0.02 \mathrm{~h}$ & $0.45 \pm 0.03 \mathrm{~g}$ & $0.65 \pm 0.06 \mathrm{f}$ & $0.85 \pm 0.05 \mathrm{e}$ \\
\hline
\end{tabular}

Note: Within rows and columns means sharing a different letter are different $(\mathrm{P}<0.05)$. Refer Table 1 for the detail of treatments. 
determination frequencies were due to the lower extents of C18:2. The higher extents of C18:1 in mango kernel oil has also been reported (Nzikou et al., 2010). Better storage stability of blends over control can also be explained by the higher concentration of C18:1, the better oxidative stability of monounsaturated oils has been well described in literature (Nadeem et al., 2013). In addition to fatty acid composition, phenolic compounds of mango kernel oil also considerably inhibited the lipid peroxidation. The phenolic content of mango kernel oil was $9.87 \mathrm{mg} \mathrm{g}^{-1}$ (Kittiphoom, 2012).

\section{Polymer Content}

Results of the polymer content of vanaspati prepared from palm oil and mango kernel oil are given in Table 4. The polymer content of experimental samples and control increased with the progression of heating cycles but to varying extents. The generation of polymer compounds in fats and oils mainly depends upon the fatty acid composition, presence and concentration of antioxidants. The addition of mango kernel oil improved the thermal stability of blends over control. Determination of polymer compounds in fats and oils is an important parameter to know their oxidative stability (Tain and Dasgupta, 1999). Vanaspati is widely used as frying media, thermal stability is one of the most important quality criteria; therefore, this parameter was included to assess the thermal stability of blends of mango kernel oil and palm oil. The results of polymer content in the current investigation can also be justified by the findings of Anwar et al. (2007), they observed that the generation of polymer compounds in successive heating cycles was mainly dependent upon the fatty acid composition, where oils with higher concentration of polyunsaturated fatty acids yielded more polymers over the oil rich in monounsaturated fatty acids.

\section{Changes in Fatty Acid Composition}

The results regarding changes in the fatty acid composition of mango kernel oil, palm oil blends during the storage period are presented in Table 5. Fatty acid profile of fats and oils change as a function of oxidative breakdown and can be used as an important indication of their storage stability (Nadeem et al., 2014). Fatty acid profile of all the treatments and control changed during the storage period of six months, however, the degree of transition from the initial value was different. Major variations were observed around C18:2, its concentration in control decreased from $22.7 \%$ to $18.53 \%$, while, C18:2 content of $\mathrm{T} 5$ decreased from $6.11 \%$ to $5.77 \%$, after six months of the storage period at ambient temperature. The lower antioxidant capacity of control can be connected to the loss of antioxidant substances in commercial processing of edible oils. The oxidisability of C18:2 is 15 times greater than C18:1 (Baer et al., 2001). The strong correlation between fatty acid composition and oxidation products has been well described (Gulla and Waghray, 2011). The better oxidative stability of monounsaturated oils has been well documented (Abdulkarim et al., 2007). Supplementation of Moringa oleifera oil $(62 \%$, oleic acid) considerably enhanced the oxidative stability of vanaspati (Nadeem et al., 2014). Supplementation of watermelon seed oil with mango kernel significantly inhibited the auto-oxidation (Azeem et al., 2015).

\section{Induction Period}

Results of induction period are given in Figure 1. Measurement of oxidative stability of fats and oils in accelerated oxidation conditions delivers beneficial information regarding their expected shelf-life, fats and oils with higher induction period usually stays well for longer periods of time. The progressive addition of mango kernel oil in palm oil improved the induction period $(\mathrm{P}<0.05)$. The amendments in fatty acid composition and increase in antioxidant capacity of blends as a function of mango kernel oil could be the justification of better oxidative stability in accelerated oxidation conditions. The antioxidant potential of mango kernel oil has been successfully employed for the stabilisation of tallow, supplementation of mango kernel oil in tallow from $1 \%-3 \%$ significantly enhanced the induction period (Jafari et al., 2014). The presence of antioxidant compounds such as mangiferrin and xanthon-C-

Table 4. POLYMER CONTENT OF MANGO KERNEL OIL AND PALM OIL BLENDS

\begin{tabular}{lcccc}
\hline Treatments & \multicolumn{4}{c}{$\%$ Polymers (heating cycles) } \\
\cline { 3 - 5 } Control & $\mathbf{0}$ & $\mathbf{1}$ & $\mathbf{2}$ & $\mathbf{3}$ \\
\cline { 3 - 5 } $\mathrm{T}_{1}$ & $0.21 \pm 0.021$ & $4.25 \pm 0.19 \mathrm{~h}$ & $9.67 \pm 0.24 \mathrm{e}$ & $21.55 \pm 0.47 \mathrm{a}$ \\
$\mathrm{T}_{2}$ & $0.22 \pm 0.031$ & $4.12 \pm 0.57 \mathrm{~h}$ & $9.55 \pm 0.74 \mathrm{e}$ & $20.97 \pm 0.88 \mathrm{a}$ \\
$\mathrm{T}_{3}$ & $0.19 \pm 0.011$ & $3.65 \pm 0.34 \mathrm{i}$ & $8.76 \pm 0.53 \mathrm{f}$ & $18.66 \pm 0.42 \mathrm{~b}$ \\
$\mathrm{~T}_{4}$ & $0.16 \pm 0.021$ & $3.22 \pm 0.39 \mathrm{j}$ & $8.19 \pm 0.29 \mathrm{f}$ & $17.61 \pm 0.51 \mathrm{c}$ \\
$\mathrm{T}_{5}$ & $0.15 \pm 0.021$ & $2.85 \pm 0.41 \mathrm{k}$ & $7.74 \pm 0.32 \mathrm{~g}$ & $15.22 \pm 0.66 \mathrm{~d}$ \\
\hline
\end{tabular}

Note: Within rows and columns means sharing a different letter are different $(\mathrm{P}>0.05)$. 


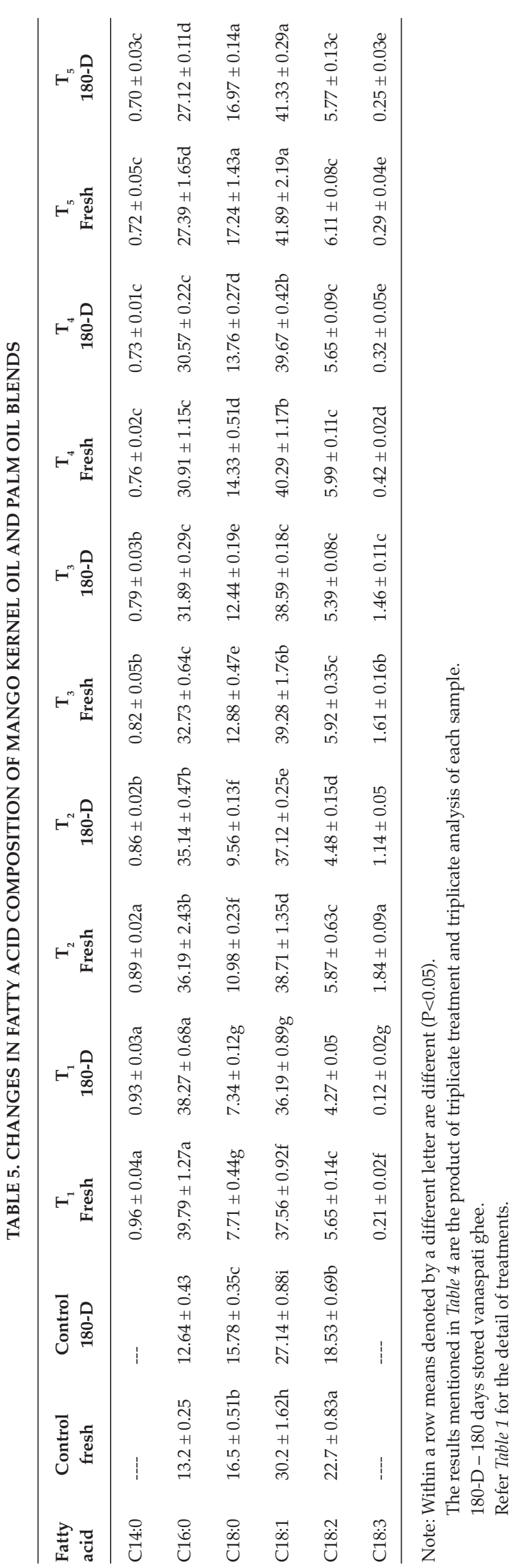

glycoside, tocopherols has been evidenced in mango kernel oil (Soong et al., 2004). The inhibition of lipid peroxidation in edible oil, supplemented with 300 ppm catechin mixture of mango kernel oil was greater than butylated hydroxyl toluene (BHT) (Zein et al., 2005). The oxidative stability of sunflower oil supplemented with $1 \%$ crude mango kernel oil in accelerated oxidation conditions was equal to 200 ppm BHT (Abdalla et al., 2007). Supplementation of buffalo fat with $5 \%$ mango kernel oil enhanced the keeping quality up to 12 months (Yousssef, 1999). Anti-inflammatory, anti-mutant, antioxidant, antiviral, anti-carcinogenic properties of gallic acid and ellagic acid has been well established, these compounds are believed to be present in appreciable concentration in mango kernel oil (Soong and Barlow, 2006). Jafari et al. (2014) described that induction period of mango kernel was $85 \mathrm{hr}$.

\section{Solid Fat Index}

Solid fat index measures the percentage of solids in fats and oils at a specific temperature ( $\mathrm{O}^{\prime}$ Brien, 2004). It is considered an important parameter in the formulation of shortenings and margarines. The similarity in solid fat index of palm oil and mango kernel provides a great deal of opportunity for usage in margarines, shortenings and other food applications (Table 6). It is usually recommended that blends of vanaspati should have a lower solid content at human body temperature. Palm oil and mango kernel oils both possess the lowest solid fat indexes at body temperature. The solid fat index of crude and refined mango kernel oil has been studied (Saiprabha et al., 2011). Muffins prepared from shortening containing 50\% mango kernel oil considerably improved their tenderness (Abdel-Razik et al., 2012). Physical and chemical characteristics of mango kernel oil were in the range of many dietary fats and oils (El-Bastawesy et al., 2007). Research work has indicated that mango kernel seed oil can be used as a source of edible oil (Mohamed and Girgis, 2005). Melting behaviour of a blend containing $40 \%$ mango kernel oil, $60 \%$ cocoa butter was similar to cocoa butter (Momeny et al., 2012).

\section{Sensory Characteristics}

The results of sensory characteristics of vanaspati formulated from mango kernel oil and palm oil blends are given in Tables 7 and 8. The colour of all the blends and French fries prepared in them were not different from each other $(p>0.05)$. The similarity in colour of substrate oils and their blends could be attributed as the justification for non-variation in colour score. The smell and taste of vanaspati blends and French fries at $T_{5}$ level (50\% palm oil and 50\% mango kernel oil) was not 


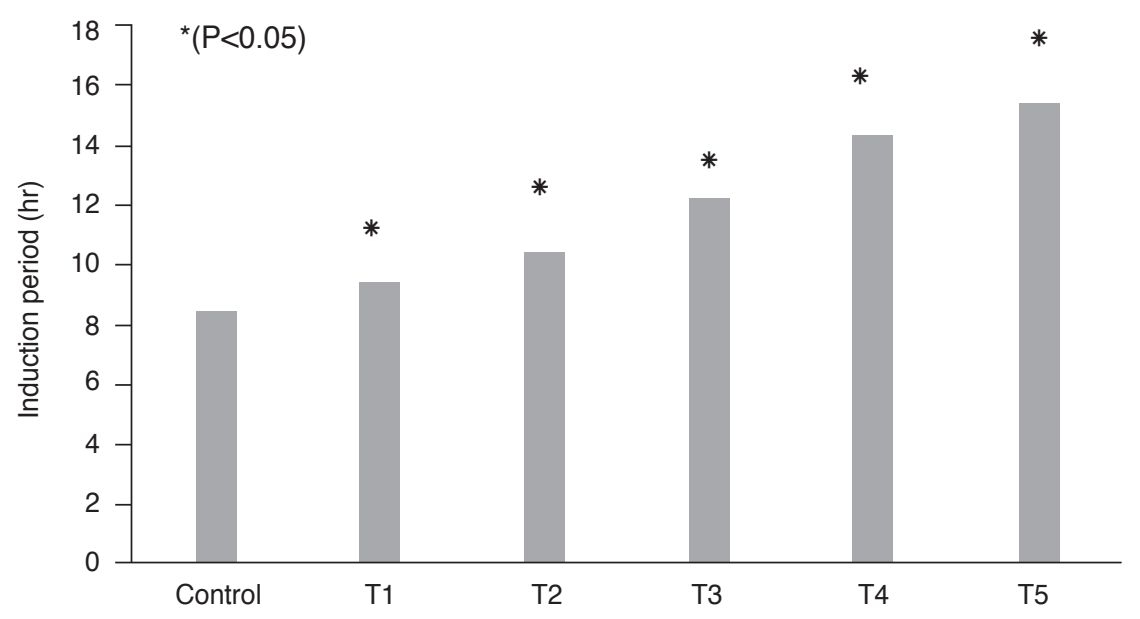

Figure 1. Induction period of mango kernel oil and palm oil-based vanaspati ghee.

TABLE 6. SOLID FAT INDEX OF PALM OIL AND MANGO KERNEL OIL BLENDS

\begin{tabular}{|c|c|c|c|c|}
\hline Treatments & $20^{\circ} \mathrm{C}$ & $25^{\circ} \mathrm{C}$ & $30^{\circ} \mathrm{C}$ & $35^{\circ} \mathrm{C}$ \\
\hline Control & $58.2 \pm 1.63 a$ & $46.7 \pm 0.97 a$ & $27.9 \pm 0.74 a$ & $12.7 \pm 1.12 \mathrm{a}$ \\
\hline $\mathrm{T}_{1}$ & $48.5 \pm 1.21 \mathrm{c}$ & $23.8 \pm 2.57$ & $12.3 \pm 0.52 \mathrm{~d}$ & $4.8 \pm 0.18 b$ \\
\hline $\mathrm{T}_{2}$ & $49.2 \pm 1.29 c$ & $25.7 \pm 1.08 \mathrm{e}$ & $12.7 \pm 0.32 \mathrm{~d}$ & $4.3 \pm 0.24 \mathrm{c}$ \\
\hline $\mathrm{T}_{3}$ & $49.8 \pm 2.36 c$ & $27.5 \pm 1.43 \mathrm{~d}$ & $13.4 \pm 0.29 c$ & $3.9 \pm 0.31 c$ \\
\hline $\mathrm{T}_{4}$ & $50.3 \pm 1.84 \mathrm{c}$ & $28.9 \pm 1.69 c$ & $13.8 \pm 0.63 c$ & $3.5 \pm 0.12 \mathrm{~d}$ \\
\hline $\mathrm{T}_{5}$ & $51.1 \pm 0.87 \mathrm{~b}$ & $31.2 \pm 1.17 \mathrm{~b}$ & $14.5 \pm 0.96 b$ & $2.8 \pm 0.13 \mathrm{e}$ \\
\hline
\end{tabular}

Note: Within a column means denoted by a different letter are statistically different $(\mathrm{P}<0.05)$.

\begin{tabular}{lccc}
\multicolumn{4}{c}{ TABLE 7. SENSORY EVALUATION OF PALM OIL AND } \\
MANGO KERNEL OIL BLENDS \\
\hline Treatments & Colour & Smell & Taste \\
\hline Control & $7.2 \pm 0.23$ & $7.8 \pm 0.25$ & $6.8 \pm 0.22$ \\
$\mathrm{~T}_{1}$ & $7.1 \pm 0.21$ & $7.6 \pm 0.14$ & $6.5 \pm 0.15$ \\
$\mathrm{~T}_{2}$ & $7.0 \pm 0.15$ & $7.5 \pm 0.24$ & $6.7 \pm 0.19$ \\
$\mathrm{~T}_{3}$ & $7.3 \pm 0.19$ & $7.7 \pm 0.21$ & $6.4 \pm 0.29$ \\
$\mathrm{~T}_{4}$ & $7.0 \pm 0.34$ & $7.9 \pm 0.15$ & $6.6 \pm 0.17$ \\
$\mathrm{~T}_{5}$ & $7.1 \pm 0.11$ & $7.5 \pm 0.10$ & $6.5 \pm 0.18$ \\
\hline
\end{tabular}

Note: Within a column of a parameter, all means are statistically non-significant $(\mathrm{P}>0.05)$.

TABLE 8. SENSORY EVALUATION OF FRENCH FRIES PREPARED IN PALM OIL AND MANGO KERNEL OIL BLENDS

\begin{tabular}{cccc}
\hline Treatments & Colour & Smell & \multicolumn{1}{c}{ Taste } \\
\hline Control & $8.6 \pm 0.42$ & $6.2 \pm 0.13$ & $8.5 \pm 0.41$ \\
$\mathrm{~T} 1$ & $8.4 \pm 0.16$ & $6.0 \pm 0.16$ & $8.1 \pm 0.026$ \\
$\mathrm{~T}_{2}$ & $8.8 \pm 0.12$ & $6.1 \pm 0.15$ & $8.2 \pm 0.22$ \\
$\mathrm{~T}_{3}$ & $8.5 \pm 0.41$ & $6.2 \pm 0.17$ & $8.4 \pm 0.28$ \\
$\mathrm{~T}_{4}$ & $8.2 \pm 0.13$ & $6.5 \pm 0.11$ & $8.3 \pm 0.12$ \\
$\mathrm{~T}_{5}$ & $8.3 \pm 0.18$ & $6.4 \pm 0.13$ & $8.0 \pm 0.08$ \\
\hline
\end{tabular}

Note: Within a column of a parameter, all means are statistically non-significant $(\mathrm{P}>0.05)$. different from control. Replacement of shortening with $50 \%$ mango kernel oil considerably improved the sensory characteristics of muffins (Abdel-Razik et al., 2012). Mango kernel oil significantly improved the sensory characteristics of cookies (Legesse and Emire, 2012). The mango seed kernel can be used in the formulation of large number of value-added food products with acceptable sensorial characteristic (Dhingra and Kapoor, 1989).

\section{CONCLUSION}

Physico-chemical and sensory characteristics of palm oil and mango kernel oil blends was comparable to market vanaspati. Mango kernel oil inhibited the oxidation of palm oil, blends underwent lower degree of oxidation, yielded the lower concentration of oxidation products. Palm oil and mango kernel oil offer wide range of trans-free options for the preparation of vanaspati at commercial scale. Blend containing 50\% mango kernel oil, 50\% palm oil revealed the superior storage stability, with no difference in sensory characteristics from market vanaspati. Mango kernel oil can be successfully used in vanaspati. 


\section{REFERENCES}

ABDALLA, E M; DARWISH, S M; AYAD, E H E and EL-HAMAHMY, R M (2007). Egyptian mango byproduct. Antioxidant and antimicrobial activities of extract and oil from mango seed kernel. Food Chem., 103: 1141-1152.

ABDEL-RAZIK, M; ASHOUSH M; NESSRIEN, I S and YASSIN, M N (2012). Characteristics of mango seed kernel butter and its effects on quality attributes of muffins. Alex J. Food Sci. Technol., 9: 1-9.

ABDULKARIM S M; LAI, O M; MUHAMMAD, S K S; LONG, K and GHAZALI, H M (2007). Oleic acid enhancement of Moringa oleifera seed oil by enzymatic transesterification and fractionation. Asian Food J., 14: 91-102.

ALONSO L; FRAGA, M J and JUAREZ, M (2000). Determination of trans fatty acids and fatty acid profiles in margarines marketed in Spain. J. Amer. Oil Chem. Soc., 7: 131-136.

ANWAR, F; HUSSAIN,AI;IQBAL, S and BHANGER, M I (2007). Enhancement of the oxidative stability of some vegetable oils by blending with Moringa oleifera oil. Food Chem., 103: 1181-1191.

AOAC (1997). Official Methods of Analysis. 16 ${ }^{\text {th }}$ edn. Association of Official Analytical Chemists, AOAC Internat. Gaithersburg, MD.

AOAC (2005). Official Methods of Analysis. Association of Official Agriculture Chemists, Washington, DC.

AOCS (1995). Official Methods and Recommended Practices of the American Oil Chemists' Society. $4^{\text {th }}$ edn. AOCS, Champaign.

AZEEM, M; NADEEM, M and SAJID, R (2015). Analytical characterization of pure and ble n d e d watermelon (Citrullus lanatus) oil: impact of blending on oxidative stability. Pak. J. Anal. Environ. Chem., 16: 52-58.

BAER, R J; RYALI, J; SCHINGOETHE, J and KASPERSON, K M; DONOVAN HIPPEN, D C and FRANKLIN, A R (2001). Composition and properties of milk and butter from cows fed fish oil. J. Dairy Sci., 84: 345-353.

DHINGRA, S and KAPOOR, A C (1989). Nutritative value of mango seed kernel. J. Sci. food Agri. 6: 752756.

EL-BASTAWESY, A M; EL-REFAI, A A and ZAKARIA, M M (2007). Grape and mango seeds as untraditional sources of edible oils, antioxidants and antibacterial compounds. Proc. of the $9^{\text {th }}$ International
Mansoura Conference on Chemistry and its Role in Development., 34: 17-36.

ERICKSON, D R (1999). Practical Handbook of Soybean Processing and Utilization. AOCS press, Champaign.

FAHIMDANESH, M and BAHRAMI, M E (2013). Evaluation of physicochemical properties of Iranian mango seed kernel oil. Second International Conference on Nutrition and Food Sciences. IACSIT Press, Singapore. DOI: 10.7763 / IPCBEE. 53 (9).

FOWOMOLA, M A (2010). Some nutrients and antinutrients contents of mango (Magnifera indica) seed. Afr. J. Food Sci., 4: 472-476.

GULLA, S and WAGHRAY, K (2011). Effect of storage on physico-chemical characteristics and fatty acid composition of selected oil blends. J. Lipid Sci., 3: 3 5-46.

JAFARI, M; GHARACHORLOO and HEMMACI, A $H$ (2014). The stabilizing effect of three varieties of crude mango seed kernel oil on tallow. J. Food Biosci. Technol., 4: 31-36.

KITTIPHOOM, S (2012). Utilization of mango seed. Int. Food Res. J., 19: 1325-1335.

KITTIPHOOM, S and SUTASINEE, S (2013). Mango seed kernel oil and its physicochemical properties. Int. Food Res. J., 20: 1145-1149.

LEGESSE, M B and EMIRE, S A (2012). Functional and physicochemical properties of mango seed kernels and wheat flour and their blends for biscuit production. Afr. J. Food Sci. Technol., 3: 193-203.

LETH, T; BYSTED, A; HANSEN, K and OVESEN, L (2003). Trans FA content in Danish margarines and shortenings. J. Amer. Oil Chem. Soc., 80: 475-478.

LOKURUKA, M N I (2007). Role of fatty acids of milk and dairy products in cardiovascular diseases: a review. Afr. J. Food Agric. Nutr. Dev., 7 (1). http: / / www.bioline.org.br

MENSINK, R P; PLAT, J and TEMME, E H M (2002). Dietary fats and coronary heart disease. Food Lipids (Akoh, C and Min, D B eds.). Marcel Decker, New York. p. 603-636.

METROHM, A G (1993). Oxidative stability of oils and fats-Rancimat method. Metrohm Application Bulletin No. 204: 1-4.

MOHAMED, E M and GIRGIS, A Y (2005). Utilization of mango seed kernels for improving stability of some oils and biscuit production. J. Agric. Sci., 30: 4625-4636. 
MOMENY, E; RAHMATI, S and RAMLI, N (2012). Effect of microwave pretreatment on the oil yield of mango seeds for the synthesis of a cocoa butter substitute. J. Food Process. Technol. 3: 6.

NADEEM, M; ABDULLAH, M and HUSSAIN, I (2013). Improvement of the oxidative stability of butter oil by blending with Moringa oleifera oil. J. Food Process. Preserv. DOI:10.1111/jfpp.12108.

NADEEM, M; AZEEM, W and RAHMAN, F (2014). Assessment of transesterified palm olein and Moringa oleifera oil blends as vanaspati substitutes. J. Food Sci. Technol. DOI 10.1007/s13197-014-1271-4.

NADEEM, M; IRMAN, M and MAHMUD, A (2016). Enhancement of the oxidative stability of butter oil by mango kernel oil in ambient and accelerated oxidation. J. Food Process. Preserv.

NZIKOU, J M; KIMBONGUILA, A; MATOS, L; LOUMOUAMOU, B; PAMBOU-TOBI, N P G; NDANGUI, C B; ABENA, A A; SILOU, T H; SCHER, J and DESOBRY, S (2010). Extraction and characteristics of seed kernel oil from mango (Mangifera indica). Res. J. Envir. Earth Sci., 2: 31-35.

O'BRIEN, R D (2004). Fats and oils. Formulating and Processing for Application. $2^{\text {nd }}$ edn. CRC Press LCC.

POTT, I; MARX, M; NEIDHART, S; MUHLBAUER, W and CARLE, R (2003). Quantitative determination of b-carotene stereoisomers in fresh, dried, and solar-dried mangoes (Mangifera indica L.). J. Agri. Food Chem., 51: 4527-4531.

RASS, M; SCHEIN, C and MATTHAUS, B (2008) Virgin sunflower oil. Eur. J. Lipid Sci. Technol., 110: 618-624.

SHAHIDI, S (2005). Bailey's Industrial Edible Oil and Fat Products. $6^{\text {th }}$ edn. Willey, NY.
SAIPRABHA, M; MAHALE and GOSWAMI-GIRI, A S (2011). Composition and characterization of refined oil compared with its crude oil from waste obtained from Mangifera indica. Asian J. Res. Chem., 4: 1415-1419.

SOONG, Y Y and BARLOW, P J (2006). Quantification of gallic acid and ellagic acid from longan (Dimocarpus longan Lour.) seed and mango (Mangifera indica L.) kernel and their effects on antioxidant activity. Food Chem., 97: 524-530

SOONG, Y Y; BARLOW, P J and PERERA, C O (2004). A cocktail of phytonutrients: identification of polyphenols, phytosterol and tocopherols from mango seed kernel. IFT Annual Meeting. Las Vegas.

STEEL, R G D; TORRIE, J H and DICKEY, D A (1997). Principles and Procedures of Statistics. A Biometrical Approach. $3^{\text {rd }}$ edn. McGraw Hill Book Co., New York.

TAIN, K and DASGUPTA, PK (1999). Determination of oxidative stability of oils and fats. Anal Chem., 71: 1692-1698.

TEKIN, A; CIZMECI, M; KARABACAK, H and KAYAHAN, M (2002). Trans FA and solid fat contents of margarines marketed in Turkey. J. Amer. Oil Chem. Soc., 79: 443-445.

XU, Y X; HANNA, M A and JOSIAH, S J (2007). Hybrid hazelnut oil characteristics and its potential oleochemical application. Indus Crops and Products, 26: 69-76.

YOUSSEF, A M (1999). Utilization of the seed of mango processing wastes as a secondary source of oil and protein. J. Agric. Res., 44: 149-166.

ZEIN, R E; EL-BAGOURY, A A and KASSAB, H E (2005). Chemical and nutritional studies on mango seed kernels. J. Agric. Sci., 30: 3285-3299. 